\title{
CD14 promoter polymorphisms associated with different allergic phenotypes and modulated by house dust mite allergy
}

\author{
Original \\ Wafaa M Zaki ${ }^{1,2}$, Hedayat A Salem ${ }^{3,4}$, Hoda M El Azizy ${ }^{5}$, Maryam E Ajeebi ${ }^{6}$ \\ Article \\ Department of Medical Parasitology, Faculty of Medicine, Suez Canal University, Ismailia, \\ Egypt $^{1}$. Departments of Medical laboratory Technology ${ }^{2}$ and Medical Biology ${ }^{3}$, Faculty of \\ Applied Medical Sciences, Jazan University, Jazan, Saudi Arabia ${ }^{2,3}$. Departments of Clinical \\ Pathology ${ }^{4}$ and Medical Biochemistry ${ }^{5}$, Faculty of Medicine, Cairo University, Egypt ${ }^{4,5}$. \\ Faculty of Medicine, Jazan University, Jazan, Saudi Arabia ${ }^{6}$
}

\begin{abstract}
Background: The house dust mite (HDM) constitutes a major cause of allergic disease all over the world; meanwhile interaction between genetic control, environmental factors in the context of allergen exposure may affect allergic phenotype. Cluster of differentiation 14 (CD14) polymorphisms play a major role in genetic control of allergic phenotypes. Objective: We aimed to assess the role of CD14 genetic polymorphisms at two loci $A(-1,145) G$, and G(-1,359)T in expression of atopic asthma and allergic rhinitis in the context of HDM exposure in Jazan, KSA.

Subjects and Methods: Through a case control study, 160 subjects served as 60 atopic asthmatic patients, 40 allergic rhinitis patients and 60 healthy non-allergic controls. Clinical and immunological parameters for the studied subjects were assessed. Then, genotyping of two single nucleotide polymorphisms (SNPs) at A(-1,145)G, and G(-1,359)T, in the promoter region of the CD14 gene was conducted using restriction fragment length polymorphisms (RFLP-PCR).

Results: The present study showed that in HDM sensitive subjects there was a significant association between GG genotype variant at $A(-1,145) G$ with atopic asthma patients and another significant association between TT genotype variant at $\mathrm{G}(-1,359) \mathrm{T}$ with allergic rhinitis patients.

Conclusion: The impact of allergy induced by HDMs may be enhanced in individuals with specific CD14 gene variants resulting in exaggerated allergic phenotype.
\end{abstract}

Keywords: allergic rhinitis, atopic asthma, CD14 gene polymorphism, house dust mites.

Received: 5 February 2019, Accepted: 23 February 2019

Corresponding Author: Wafaa M. Zaki, Tel.: 01005240384, E-mail: Wafaa_Zaki@hotmail.com

Print ISSN: 1687-7942, Online ISSN: 2090-2646, Vol. 12, No. 1, April, 2019.

\section{INTRODUCTION}

House dust mites (HDMs), are tiny microscopic Acarida. The most predominant HDM isolated from dust samples are Dermatophagoides pteronyssinus (D. $p$ ) and Dermatophagoides farina (D. f). Dust mites thrive at a temperature of $20-25^{\circ} \mathrm{C}$ and humidity levels of $70-80 \%$. Most mites die in low humidity levels or extreme temperatures, leaving the dead bodies and waste behind, predisposing to allergic reactions ${ }^{[1]}$. More than twenty different allergens that elicited specific IgE responses in sensitized patients were identified in both species ${ }^{[2]}$. These allergens are categorized into four groups: proteases, proteins that possess affinities for lipids, non-proteolytic enzymes, and nonenzymatic components ${ }^{[3]}$. They live in household dust and are recognized as one of the most common air born allergens sources all over the world. A record of more than $15-20 \%$ of the population from industrialized countries are affected by HDM sensitization ${ }^{[4]}$. Allergic sensitization is defined by IgE production against environmental antigens such as HDMs, grass pollen, and animal proteins which can lead to diseases including asthma, rhinitis, and atopic dermatitis ${ }^{[5]}$.
Asthma is a complex disease in which genetic and environmental factors both lead to the diseased state ${ }^{[4]}$. Pathogen associated molecular patterns (PAMPs) are complexes present in pathogens but absent in the host ${ }^{[6]}$. During an infection, PAMPs are recognized by macrophages via toll-like receptors (TLRs). Stimulation of TLRs causes dendritic cell activation that establishes contact between peripheral and lymphatic tissues; which in turn activates the T cells, this being the most important part of the acquired immune system[7]. Experimental evidences suggest that HDM allergen specific Th2 cells play a key role in the allergic inflammatory response which leads to allergen specific IgE production, the drafting of eosinophils in tissues, the permissiveness of endothelium for the recruitment of inflammatory cells to inflamed lungs, the reproduction of mucous, and the modulation of the airway smooth muscle contraction ${ }^{[8]}$.

It is becoming clear that as compared to the single gene expression, the complex gene interaction with the environment enhances the allergic reaction and disease with variable degrees ${ }^{[2]}$. Polymorphisms 
within innate immunity genes are associated with different allergic phenotypes, with variable results ${ }^{[9]}$. A multifunctional receptor $\mathrm{CD} 14$ is present on macrophages and monocytes where it binds with endotoxin and other bacterial wall components then facilitates the lipopolysaccharide presentation to TLR4 and thus promote immune activation ${ }^{[10]}$. The gene encoding CD14 seems to be among one of many genes that add to the allergic phenotype expression because it is localized on chromosome 5 q31.1; a region which is linked to both asthma and total serum IgE concentration $^{[11]}$. CD14 exists as a single-copy gene, having its protein in two distinct forms: a $55-\mathrm{kDa}$ membrane molecule (mCD14) expressed primarily on the surface of monocytes/macrophages, dendritic cells and neutrophils, and a soluble form (sCD14) in serum $^{[12]}$. Furthermore, Vercelli et al., ${ }^{[13]}$ characterized five SNPs (at positions -1,619, -1,359, -1,145, - 809, and -159) in the promoter of the gene encoding CD14. The effect of the CD14 -159 genotype (CC, TT or CT) on the asthma phenotype in terms of total IgE levels, can also be different. Numerous studies have been conducted to investigate the relationship between CD14 variants and total IgE levels ${ }^{[14-16]}$. It is noted that carriers of the $-1,359 \mathrm{~T} /-1,145 \mathrm{~A} /-159 \mathrm{C}$ haplotype had the highest levels of IgE, and the lowest levels of sCD14 and, conversely, carriers of the $-1,359 \mathrm{G} /-1,145 \mathrm{G} /-159 \mathrm{~T}$ haplotype had the highest levels of sCD14 and the lowest IgE values ${ }^{[13]}$.

Exposure to endotoxins may trigger allergic disease, but the genetic factors may affect the degree of response ${ }^{[17,18]}$. Similarly the atopic condition of the host may modulate the effect of endotoxins. It has been found that during allergy development, the genetic variants C-159T, C-260T and C-1,721T within CD14 interact with environmental factors ${ }^{[19]}$. A CD14/-159 CC genotype was associated with increased specific bronchial hyper-reactivity to Der $p 1$ allergen and higher concentrations of HDM specific $\operatorname{IgE}^{[15]}$.

The aim of our study is to assess the role of CD14 $\mathrm{A}(-1,145) \mathrm{G}$, and $\mathrm{G}(-1,359) \mathrm{T}$ polymorphisms in the expression of atopic asthma and allergic rhinitis in the context of HDM exposure in Jazan, KSA.

\section{SUBJECTS AND METHODS}

Through a case control study, a total of 160 individuals were enrolled, serving as 100 patients: 60 with atopic asthma, and 40 with allergic rhinitis, and 60 non-allergic healthy controls. The study subjects were Saudi citizens recruited from three Jazan general hospitals (Prince Bin- Nasser, Abu-Erish, and Sabia) during the period between September, 2017 to September, 2018.

Subjects: Selection of patients was based on the complaint of recurrent dyspnea, cough, wheeze, chest tightness, history of short attacks of breathlessness and allergic symptoms or a history of allergy. Patients who were suffering from upper or lower respiratory tract infections at the time of the study or who were on steroid therapy, on specific allergen immunotherapy or those who had a personal or family history of tuberculosis, were excluded. Asthma was diagnosed by the physician according to the global initiative for asthma (GINA) guidelines ${ }^{[20]}$. Allergic rhinitis patients had symptoms of sneezing, rhinorrhea, nasal obstruction, runny nose and/or itchy nose.

Clinical and laboratory evaluation: All subjects completed a uniformly structured detailed questionnaire to obtain their sociodemographic and clinical data. In addition, an objective evaluation of bronchial responsiveness and involvement was performed by a spirometric test to assess forced expiratory volume in one second (FEV1) ${ }^{[21]}$.

Environmental exposure: Dust samples were collected from all subjects' houses. Dust of one meter square of the carpet, armchair, sofa, or other upholstered piece of furniture in the bedroom for 2-3 min was obtained using portable vacuum cleaner $300 \mathrm{~W}$. Presence of HDM was determined by sieving of $1 \mathrm{gm}$ house dust sample through 300 mesh brass sieve of $6 \mathrm{~mm}$ diameter to remove large particles and fibrous materials. Then mites were isolated from the dust samples in a $5 \mathrm{~cm}$ glass Petri dish under a dissecting microscope 20x with the aid of a fine camel brush $(000)^{[22]}$. Positive cases selected were those with positive house dust specimen, while control subjects who had a positive specimen were excluded and replaced with another who had a negative specimen.

Measurement of $\operatorname{Der} p 1$ allergen concentrations ${ }^{[16]}$ : Evaluation in house dust samples were done using ELISA kits for antigen quantitation (INDOOR Biotechnologies Inc., Charlottesville, VA, USA) according to manufacturer's instructions.

HDMs allergy evaluation: All atopic patients were subjected to skin prick testing for responsiveness to the following aeroallergens (HDM, mould mix, grass pollen mix, thresher dust, paper mulberry and mixed food), (Allergopharma, Reinbek bei Hamburg, Germany). Positivity was identified as presence of a reaction to one or more aeroallergens with a wheel diameter $\geq$ $3 \mathrm{~cm}$. Measurement of total $\operatorname{IgE}^{[16]}$ was done for all studied subjects by ELISA test kit (Human Gesllschaft for biochemical and diagnostic, Max Plank, and Germany) following the manufacturer's instructions. Samples absorbance were read using microtiter plate reader at absorbance of 450/620 nm. Samples were tested in duplicate to ensure reliability, under strict sterile conditions. Measurement of IgE specific to Der $p 1^{[16]}$ was measured by ELISA test kit (Astra Biotech GmbH Rudower Chaussee 2912489 Berlin, Germany) according to manufacturer's instructions. 
Genotyping of CD14 promoter region polymorphism by PCR-RFLPs ${ }^{[23]}$ : Genomic DNA was isolated from peripheral blood cells, and DNA was extracted from the whole blood using a DNA extraction kit, (QIA amp DNA Mini kit (Cat. No. 51304; Qiagen Inc, Valencia, CA), following the manufacturer's instructions. Genomic DNA was quality checked by agarose gel electrophoresis analysis, quantified spectrophotometrically, and stored at $-80^{\circ} \mathrm{C}$. Genotyping of $\mathrm{CD} 14$ promotor region was performed by PCR-RFLPs as follows: the polymorphism $\mathrm{A}(-1,145) \mathrm{G}$ was typed using a sense (5'-CTCAGGAATCTGAGGCAAGA-3') and reverse (5'-AGTACAATCTCTGTGCCCTA-3') primer pair (Table 1).

The PCR amplification was performed in $25 \mu$ reaction volume containing $12.5 \mu 2 \mathrm{x}$ PCR master mix; 2x PCR buffer, $3 \mathrm{mM} \mathrm{MgCl}_{2}, 0.5$ unit Taq DNA polymerase $/ \mu \mathrm{l}, 400 \mu \mathrm{M}$ of each dNTP, $1 \mu$ of each primer (10 pmol), $2.5 \mu \mathrm{l}$ of genomic DNA, and $8 \mu \mathrm{l}$ sterilized nuclease free water. The reaction was performed in a Gene Ampl.9700 (A Hybaid thermal cycler, Promeg Corporation 2008 Woods Hollow Road Madison, W11 53711-5399, USA). The program was as follows: initial denaturation at $94^{\circ} \mathrm{C}$ for $5 \mathrm{~min}, 35$ cycles of $30 \mathrm{~s}$ denaturation at $94^{\circ} \mathrm{C}, 30 \mathrm{~s}$ annealing at $56^{\circ} \mathrm{C}$ and $1 \mathrm{~min}$ extension at $72^{\circ} \mathrm{C}$, and a $5 \mathrm{~min}$ final extension at $72^{\circ} \mathrm{C}$. The amplified product was detected in $2 \%$ agarose gel as a single band at $371 \mathrm{bp}$ in length. Following PCR, the product was digested with HPYCH4V (Cat. NO. R0945) for $1 \mathrm{~h}$ at $37^{\circ} \mathrm{C}$. The product yielded bands of $300 \mathrm{bp}$ in GG homozygotes, $230 \mathrm{bp}$ in AA homozygotes and the two bands in heterozygotes.

The polymorphism $\mathrm{G}(-1,359) \mathrm{T}$ was typed using the same primer pair as for $\mathrm{A}(-1,145) \mathrm{G}$. After PCR, the product was digested with $2 \mu$ FOK1 (New England Bio Lab) for $1 \mathrm{~h}$ at $37^{\circ} \mathrm{C}$. The PCR product was $371 \mathrm{bp}$ in length. Digestion of the PCR product yielded bands of 178 and 146 bp in GG homozygotes, 146, 112, and 66 $\mathrm{bp}$ in TT homozygotes, and all bands in heterozygotes.

Statistical analysis: Statistical analysis was done using SPSS V16 (SPSS Inc, Chicago, USA). Genotype frequencies were determined, and comparisons of the frequencies were performed by Chi square test $\left(\chi^{2}\right)$ using $2 \cdot 2$ frequencies. Comparison between cases and controls were calculated using $\chi^{2}$ test. Allele odds ratio (OR) and confidence intervals (CI) were computed. $P$ value was considered statistically significant when less than 0.05 .

Ethical considerations: Informed written consent was provided for each participant to sign, after being informed with the aim of the study. The study protocol was approved by ethical committee of the medical research center Jazan University.

\section{RESULTS}

Clinical and immunological characteristics of study population: A total of 160 Saudi subjects were enrolled in this study, they were classified as 60 atopic asthmatic patients, 40 patients with allergic rhinitis and 60 age and sex matched healthy controls. Recovery of HDMs from dust specimen from atopic patients was proved (Figure 1).

It was found that about $92 \%$ of atopic asthmatics and $80 \%$ of allergic rhinitis patients showed positive skin prick test to at least one allergen, meanwhile $12 \%$ of control showed positive skin prick test to allergens other than HDM. Spirometric assessment for the study population revealed lower predicted percentage of forced expiratory volume 1 (FEV1) in atopic asthmatics and allergic rhinitis patients compared to control group. Statistical difference for total IgE level was significant when comparing atopic asthma to control $(P<0.001)$ and when comparing allergic rhinitis to control $(P=0.03)$ (Table 2).

Genotype frequency of the CD14 promoter region: Frequencies of transition at nucleotide $A$ to $G$ at position $-1,145 \mathrm{~A}(-1,145) \mathrm{G}$ and $\mathrm{a} G$ to $\mathrm{T}$ at position $-1,359 \mathrm{G}(-1,359) \mathrm{T}$ from the transcription start site in the promoter region of the CD14 gene were assessed in each of the study subjects using RFLP-PCR (Figures 2-5). Table (3) shows difference between atopic patients and

Table 1. Primers and restriction enzymes used for determination of polymorphisms of the gene encoding CD14.

\begin{tabular}{|c|c|c|c|}
\hline Polymorphism & Primers & Enzyme & PCR product size \\
\hline$A(-1,145) G$ & $\begin{array}{l}\text { '5-CTCAGGAATCTGAGGCAAGA-'3 } \\
\text { 5'-AGTACAATCTCTGTGCCCTA-'3 }\end{array}$ & HPYCH4V & $371 \mathrm{bp}$ \\
\hline$G(-1,359) T$ & $\begin{array}{l}\text { 5'-CTCAGGAATCTGAGGCAAGA-'3 } \\
\text { 5'-AGTACAATCTCTGTGCCCTA-'3 }\end{array}$ & FOK1 & $371 \mathrm{bp}$ \\
\hline
\end{tabular}
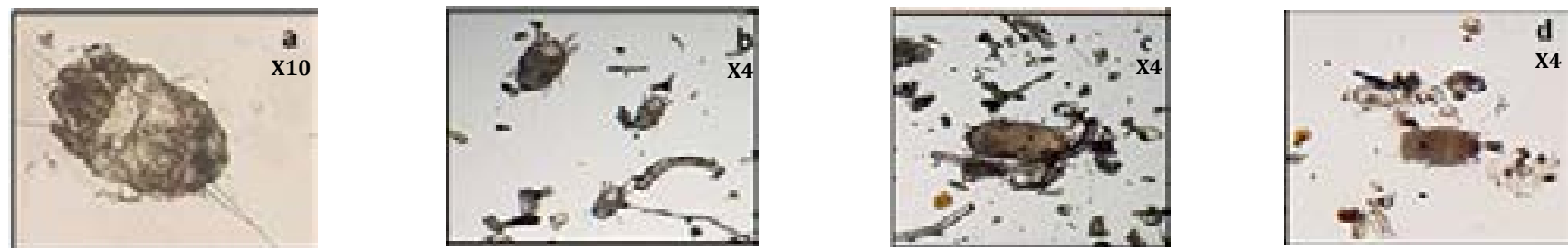

Fig. 1. House dust mites under light microscope 
Table 2. Comparative characteristics of atopic asthma, allergic rhinitis and control subjects.

\begin{tabular}{|c|c|c|c|c|}
\hline \multirow{2}{*}{ Characteristic } & \multicolumn{2}{|c|}{ Patients } & \multirow{2}{*}{ Control (60) } & \multirow{2}{*}{$\begin{array}{c}\text { Statistical analysis } \\
P \text { value }\end{array}$} \\
\hline & Atopic asthma (60) & Allergic rhinitis (40) & & \\
\hline Age (years) (Mean \pm SD) & $18.6 \pm 7.9$ & $20.4 \pm 5.3$ & $19.4 \pm 1.7$ & Asthma:0.44, Rhinitis:0.17 \\
\hline Gender (M/F) No. (\%) & $27 / 33(45 / 55 \%)$ & $18 / 22(45 / 55 \%)$ & $38 / 32(47 / 53 \%)$ & Asthma:0.27, Rhinitis:0.32 \\
\hline Positive SPT No. (\%) & $55(92 \%)$ & $32(80 \%)$ & $7(12 \%)$ & $\begin{array}{l}\text { Asthma: }<0.001^{*}, \\
\text { Rhinitis: }<0.001^{*}\end{array}$ \\
\hline $\begin{array}{l}\text { Predicted FEV1 (\%) } \\
(\text { Mean } \pm \text { SD) }\end{array}$ & $69.3 \pm 2.3$ & $76.8 \pm 2.4$ & $89.7 \pm 3.1$ & $\begin{array}{l}\text { Asthma: }<0.001^{*} \\
\text { Rhinitis: }<0.001^{*}\end{array}$ \\
\hline $\begin{array}{l}\text { Serum total IgE (IU) } \\
(\text { Mean } \pm \text { SD) }\end{array}$ & $1060.5 \pm 410.9$ & $812.4 \pm 67.1$ & $91.2 \pm 31.6$ & $\begin{array}{l}\text { Asthma: }<0.001^{*}, \\
\text { Rhinitis: }=0.03^{*}\end{array}$ \\
\hline $\begin{array}{l}\text { Serum specific Der } p \text { I IgE (IU) } \\
\text { (Mean } \pm \text { SD) }\end{array}$ & $85.06 \pm 17.9$ & $54.18 \pm 12.4$ & 0 & $\begin{array}{l}\text { Asthma: }<0.0001^{*}, \\
\text { Rhinitis: }<0.0001^{*}\end{array}$ \\
\hline
\end{tabular}

M: Male, F: Female, SPT: Skin Prick Test, FEV1: Forced expiratory volume in one second, *: Significant.

control group, there was no difference between the two groups except for $\mathrm{GG}$ genotype $(P=0.03)$. Although AA variant of CD14/-1,145 gave a statistically significant value $(P=0.04)$, but it was not considered because its significance was toward number of controls, not number of patients (33\% vs 19\%).

When the study population was stratified according to phenotypic allergy, comparison of atopic asthma and allergic rhinitis with control group revealed association between $A(-1,145) G$ and atopic asthma phenotype specially GG genotype $(P=0.007)$, with OR $(95 \% \mathrm{CI})$ $=3.05$ (1.35-6.89), and significant dominance for $\mathrm{G}$ allele $(P=0.02)$. Although in atopic asthma patients AA variant of CD14/-1,145 and A allele \% gave statistically significant values $(P=0.04$, and 0.02 , respectively), in

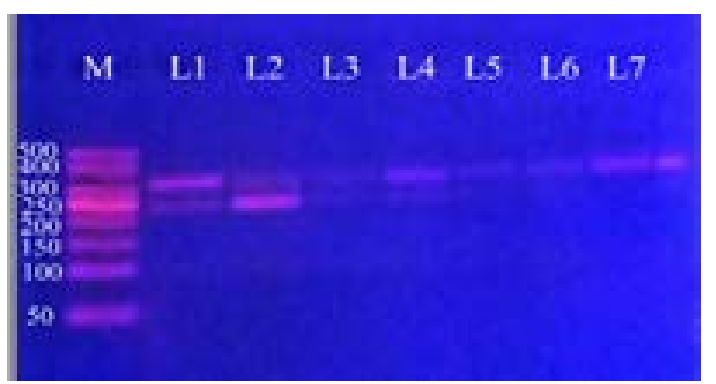

Fig. 2. Representative results of PCR-RFLP analysis and genotyping of atopic patients for $\mathrm{A}(-1,145) \mathrm{G}$ after digestion by HPYCH4V. GG at $300 \mathrm{bp}, \mathrm{AA}$ at $230 \mathrm{bp}$, and AG at $300 \mathrm{bp}$ and $230 \mathrm{bp}$. M: Marker, Lanes 1-4: AG, Lanes 5-7: GG.

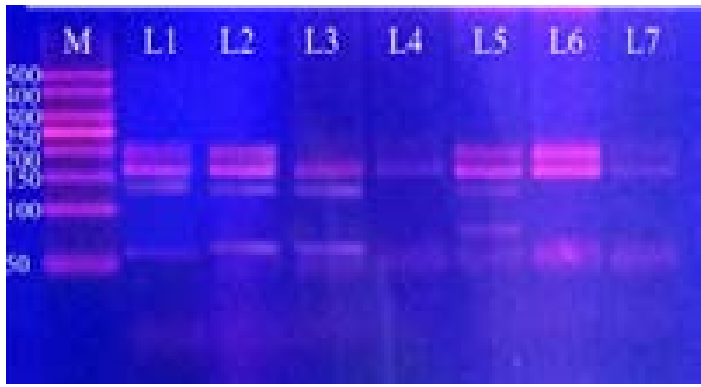

Fig. 4. Representative results of PCR-RFLP analysis and genotyping of atopic patients for $\mathrm{G}(-1,359) \mathrm{T}$, after digestion by FoK1. GG at 178 and 146 bp, TT at 146, 112, and $66 \mathrm{bp}$, GT at 178, 146, 112 and 66 bp. M: Marker, Lanes 1, 2, 5: GT, Lanes 3, 4, 7: TT, Lane 6: GG. comparison with controls, but it was not taken into consideration because its significance was toward controls and not toward patients with atopic asthma (33\% vs $17 \%$, and $57 \%$ vs $37 \%$, respectively). On the other hand, G(-1,359)T was found to be associated with allergic rhinitis phenotype with significant difference for TT homozygous allele $(P=0.01)$ (Table 4$)$.

The association of CD14 promoter region genotypes with HDM antigen concentration: When the study population was divided according to HDMs allergen concentration (Der $p 1)$, there was a significant difference of genotype distributions at $A(-1,145) G$ for homozygote GG genotype only $(P=0.02)(55 \%$ vs $31.5 \%, \mathrm{OR}=2.63,95 \%$ CI 1.12 to 6.13 ) (Table 5).

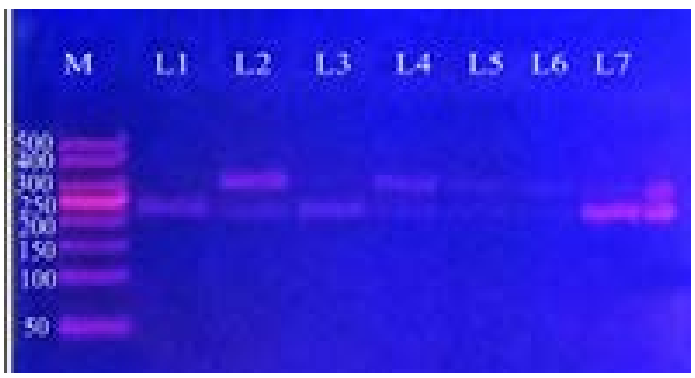

Fig. 3. Representative results of PCR-RFLP analysis and genotyping of control for $A(-1,145) G$, after digestion by HPYCH4V. GG at $300 \mathrm{bp}, \mathrm{AA}$ at $230 \mathrm{bp}$, and $\mathrm{AG}$ at $300 \mathrm{bp}$ and 230 bp. M: Marker, Lanes 1, 3, 7: AA, Lanes 2, 4. 5, 6: AG.

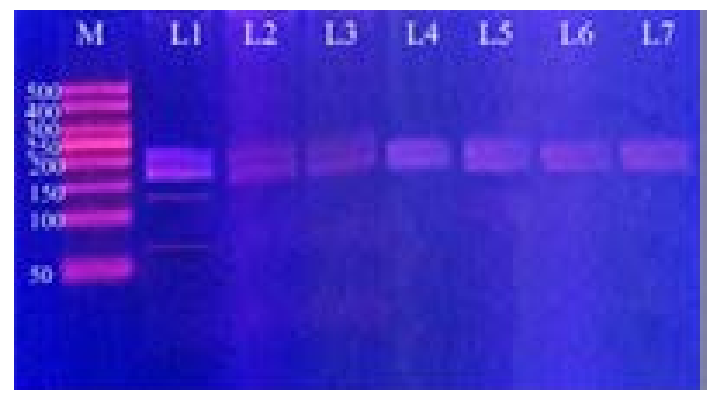

Fig. 5. Representative results of PCR-RFLP analysis and genotyping of control for $\mathrm{G}(-1,359) \mathrm{T}$, after digestion by FoK1. GG at 178 and $146 \mathrm{bp}$, TT at 146, 112, and $66 \mathrm{bp}$, GT at 178, 146, 112 and 66 bp. M: Marker, Lane 1: GT, Lanes 2-7: GG. 
PARASITOLOGISTS UNITED JOURNAL

Table 3. Genotype - allele distribution in atopic subjects and control group using RFLP-PCR.

\begin{tabular}{|c|c|c|c|c|}
\hline \multirow{2}{*}{$\begin{array}{l}\text { Genotypes/ } \\
\text { Alleles (SNP) }\end{array}$} & \multirow{2}{*}{$\begin{array}{c}\text { Atopic patients }(\text { No. }=100) \\
\text { No. }(\%)\end{array}$} & \multirow{2}{*}{$\begin{array}{c}\text { Control group }(\text { No. }=60) \\
\text { No. }(\%)\end{array}$} & \multicolumn{2}{|c|}{ Statistical analysis } \\
\hline & & & $P$ value & OR $(95 \% \mathrm{CI})$ \\
\hline \multicolumn{5}{|l|}{ CD14/-1,145 } \\
\hline AA & $19(19 \%)$ & $20(33 \%)$ & $0.04^{* *}$ & $0.46(0.22-0.97)$ \\
\hline AG & $45(45 \%)$ & $28(47 \%)$ & 0.83 & $0.93(0.49-1.77)$ \\
\hline GG & $36(36 \%)$ & $12(20 \%)$ & $0.03^{*}$ & $2.25(1.05-4.77)$ \\
\hline A\% & $41(41 \%)$ & $34(57 \%)$ & 0.05 & $0.53(0.27-1.01)$ \\
\hline G\% & $59(59 \%)$ & $26(43 \%)$ & 0.05 & $1.88(0.98-3.59)$ \\
\hline \multicolumn{5}{|l|}{ CD14/-1,359 } \\
\hline GG & $27(27 \%)$ & $18(30 \%)$ & 0.15 & $1.70(0.81-3.57)$ \\
\hline GT & $39(39 \%)$ & $26(43 \%)$ & 0.58 & $0.83(0.43-1.60)$ \\
\hline TT & $34(34 \%)$ & $16(27 \%)$ & 0.33 & $1.41(0.69-2.87)$ \\
\hline G\% & $46(46 \%)$ & $31(52 \%)$ & 0.48 & $0.79(0.41-1.51)$ \\
\hline T\% & $54(54 \%)$ & $29(48 \%)$ & 0.48 & $1.25(0.66-2.38)$ \\
\hline
\end{tabular}

Chi square $\left(\chi^{2}\right)$ test was used. OR: Odds ratio; CI: Confidence intervals, ${ }^{*}$ Significant, ${ }^{* *}$ Non significant because its significance is toward controls, not patients.

Table 4. Genotype-allele distribution in patients with atopic asthma/allergic rhinitis and control group.

\begin{tabular}{|c|c|c|c|c|c|c|c|}
\hline \multirow{3}{*}{$\begin{array}{c}\text { Genotypes/ } \\
\text { Alleles (SNP) }\end{array}$} & \multirow{3}{*}{$\begin{array}{l}\text { Control group } \\
\text { (No. = 60) }\end{array}$} & \multicolumn{3}{|c|}{ Atopic asthma (No. = 60) } & \multicolumn{3}{|c|}{ Allergic rhinitis (No. $=40$ ) } \\
\hline & & \multirow{2}{*}{ No. (\%) } & \multicolumn{2}{|c|}{ Statistical analysis } & \multirow{2}{*}{ No. (\%) } & \multicolumn{2}{|c|}{ Statistical analysis } \\
\hline & & & $P$ value & OR $(95 \% \mathrm{CI})$ & & $P$ value & OR (95\% CI) \\
\hline \multicolumn{8}{|l|}{ CD14/-1,145 } \\
\hline AA & $20(33 \%)$ & $10(17 \%)$ & $0.04^{* *}$ & $3.5(0.68-30.56)$ & $09(23 \%)$ & 0.24 & $0.58(0.23-1.45)$ \\
\hline AG & $28(47 \%)$ & $24(40 \%)$ & 0.43 & $0.85(10.2-23.71)$ & $21(52 \%)$ & 0.56 & $1.26(0.56-2.81)$ \\
\hline GG & $12(20 \%)$ & $26(43 \%)$ & $0.007^{*}$ & $3.05(1.35-6.89)$ & $10(25 \%)$ & 0.55 & $1.33(0.51-3.46)$ \\
\hline A\% & $34(57 \%)$ & $22(37 \%)$ & $0.02^{* *}$ & $0.44(0.21-0.92)$ & $19(47.5 \%)$ & 0.54 & $1.32(0.53-3.25)$ \\
\hline G\% & $26(43 \%)$ & $38(63 \%)$ & $0.02^{*}$ & $2.25(1.08-4.69)$ & $21(52.5 \%)$ & 0.36 & $1.44(0.64-3.22)$ \\
\hline \multicolumn{8}{|l|}{ CD14/-1,359 } \\
\hline GG & $18(30 \%)$ & $19(37 \%)$ & 0.84 & $1.08(0.49-2.34)$ & $08(20 \%)$ & 0.26 & $0.58(0.22-1.51)$ \\
\hline GT & $26(43 \%)$ & $27(45 \%)$ & 0.85 & $1.06(0.52-2.91)$ & $12(30 \%)$ & 0.18 & $0.56(0.24-1.30)$ \\
\hline TT & $16(27 \%)$ & $14(23 \%)$ & 0.67 & $0.83(0.36-1.91)$ & $20(50 \%)$ & $0.01 *$ & $2.7(1.18-6.39)$ \\
\hline G\% & $31(52 \%)$ & $32(53 \%)$ & 0.85 & $1.06(0.52-2.18)$ & $14(35 \%)$ & 0.11 & $0.5(0.22-1.14)$ \\
\hline T\% & $29(48 \%)$ & $28(47 \%)$ & 0.85 & $0.93(0.45-1.91)$ & $26(65 \%)$ & 0.11 & $1.9(0.87-4.52)$ \\
\hline
\end{tabular}

Table 5. Genotype allele distribution in HDM-sensitized patients with allergen concentration more and less than $2 \mu \mathrm{g} / \mathrm{g}$ dust.

\begin{tabular}{|c|c|c|c|c|}
\hline \multirow{2}{*}{$\begin{array}{c}\text { Genotypes/ } \\
\text { Alleles (SNP) }\end{array}$} & \multicolumn{2}{|c|}{ Antigen concentration ( $\mu \mathrm{g} / \mathrm{g}$ dust) } & \multicolumn{2}{|c|}{ Statistical analysis } \\
\hline & $\leq 2($ No. $=62)$ No. $(\%)$ & $>2($ No. $=38)$ No. $(\%)$ & $P$ value & OR (95\% CI) \\
\hline \multicolumn{5}{|l|}{ CD14/-1,145 } \\
\hline AA & $14(23 \%)$ & $14(37 \%)$ & 0.12 & $0.50(0.20-1.21)$ \\
\hline AG & $14(23 \%)$ & $12(31.5 \%)$ & 0.32 & $0.63(0.25-1.56)$ \\
\hline GG & $34(55 \%)$ & $12(31.5 \%)$ & $0.02 *$ & $2.63(1.12-6.13)$ \\
\hline A\% & $21(34 \%)$ & $20(53 \%)$ & 0.06 & $0.46(0.20-1.05)$ \\
\hline G\% & $41(66 \%)$ & $18(47 \%)$ & 0.06 & $2.16(0.94-4.95)$ \\
\hline \multicolumn{5}{|l|}{ CD14/-1,359 } \\
\hline GG & $16(26 \%)$ & $8(21 \%)$ & 0.58 & $1.30(0.49-3.42)$ \\
\hline GT & $18(29 \%)$ & $12(32 \%)$ & 0.78 & $0.88(0.36-2.12)$ \\
\hline TT & $28(45 \%)$ & $18(47 \%)$ & 0.82 & $0.91(0.40-2.05)$ \\
\hline G\% & $25(40 \%)$ & $14(37 \%)$ & 0.72 & $1.15(0.50-2.66)$ \\
\hline $\mathbf{T} \%$ & $37(60 \%)$ & $24(63 \%)$ & 0.72 & $0.86(0.37-1.98)$ \\
\hline
\end{tabular}




\section{DISCUSSION}

Variable results for association between functional polymorphisms in CD14 and different allergic diseases were found. It depends, to a large extent, on both environmental and genetic factors. Innate immunity genes that regulate the relationship between the immune system and pathogens such as mite allergens, are supposed to have a critical function in the development of allergic diseases ${ }^{[24]}$. Results of the present study showed a significant correlation between total IgE levels and allergic patients when compared to control group. On the other hand, no significant difference was detected in total serum IgE on comparing atopic asthma to allergic rhinitis patients as all allergic subjects showed high level of IgE. Meanwhile, other studies that correlate serum total IgE to specific CD14 genotype revealed conflicting results. Kusunoki et al., ${ }^{[25]}$ postulated that CD14 can have a dual effect on atopy by inhibiting IgE production before allergic inflammation, then stimulating IgE after its onset.

A study conducted in Taiwan proved that carriers of the CD14 -159C/-1,145A/and -1,359T haplotype had the highest IgE and lowest serum CD14 levels as compared to other haplotypes ${ }^{[23]}$. The association between markers of atopy such as skin prick tests positivity or total serum IgE concentration and the C-159T polymorphism was demonstrated in nonHispanic but not in Hispanic American population, suggesting environmental rather than genetic factor ${ }^{[17]}$. Activation of CD14 appears to up regulate IL-4 and IL12- dependent IgE production ${ }^{[9,23,26,27]}$. In this way, the effect of endotoxins and consequently IgE may vary according to the atopic condition of the host ${ }^{[28]}$.

Many hypotheses have been raised to investigate pathogenic mechanisms underlying allergy in HDM sensitization. Der-1 was found to target multiple proteins involved in the control of IgE synthesis and production $^{[29]}$, degradation of endogenous protease inhibitors $^{[30]}$, and surfactant proteins ${ }^{[31]}$. Moreover, it was suggested to increase the contact between allergens and dendritic cells (antigen presenting cells) beneath the bronchial epithelial barrier cleavage of the epithelial tight junctions by their proteolytic activities followed by release of chemokines and other mediators (e.g., IL13 , IL-33 and IL-25 ${ }^{[32]}$. A recent study proposed that Der-1 activates human receptor MRGPRX1 enhancing IL-6 production which contributes in pathogenesis of allergic rhinitis and allergic asthma ${ }^{[33]}$.

Frequencies of transition at nucleotide $A$ to $G$ at position $-1,145 \mathrm{~A}(-1,145) \mathrm{G}$ and $\mathrm{a} G$ to $\mathrm{T}$ at position $-1,359 \mathrm{G}(-1,359) \mathrm{T}$ from the transcription start site in the promoter region of the CD14 gene were assessed in each study subjects by using RFLP-PCR. In the present study, there was a significant difference $(P=0.03)$ between atopic patients and the control group for GG genotype. Innate immunity genes that regulate the relationship between immune system and pathogens like mite allergens, are supposed to have a critical function in the development of allergic disease ${ }^{[24]}$. Most studies investigated C(-159)T; however, A($1,145) \mathrm{G}$ and $\mathrm{G}(-1,359) \mathrm{T}$ rather than $\mathrm{C}(-159) \mathrm{T}$ could be involved in various atopic conditions, since tight linkage disequilibrium has been observed in both polymorphisms ${ }^{[34]}$.

When the study population was stratified according to phenotypic allergy (Table 4), there was a statistically significant association between GG homozygotes polymorphisms at $\mathrm{CD} 14 \mathrm{~A}(-1,145) \mathrm{G}$ in asthmatic patients as compared to control group $(P=0.007)$ with significant dominance for $\mathrm{G}$ allele $(P=0.02)$ as shown in figures (2) and (3). In accordance with our study, in Pakistani population Micheal et al., ${ }^{[35]}$ proved that the $\mathrm{A}(-1,145) \mathrm{G}$ polymorphism is associated with atopic asthma at GG genotype, while C(-159)T was associated with allergic rhinitis. Meanwhile in a Brazilian study conducted by de Faria et al., ${ }^{[36]}$ significant association between TT at C(-159)T genotype and severe asthma was found. In addition, they suggested a role of this genotype in modulation of asthma. A study conducted in Saudi Arabia ${ }^{[37]}$ that assessed the role of $C(-159) \mathrm{T}$, $\mathrm{A}(-1,145) \mathrm{G}$ and $\mathrm{G}(-1,359) \mathrm{T}$ in association with asthma, concluded that the heterogeneous genotypes $\mathrm{CT}, \mathrm{AG}$ and GT were the highest prevalent genotypes among asthmatic patients.

Furthermore, in the current study it was shown that there was a statistically significant association between CD14 gene $G(-1,359) T$ polymorphism in TT genotypes in case of allergic rhinitis phenotype as compared to control group $(P=0.01)$. These findings are in agreement with different studies among other populations, e.g. in Chinese patients with allergic rhinitis, TT homozygotes are more common than other genotypes ${ }^{[38]}$. In a study for association of CD14, C(-159)T, G(-1,359) $\mathrm{T}$ with expression of asthma, croup, and allergy in Canadian children, it was established that those with TT combination were significantly more likely to have asthma ${ }^{[39]}$. Also, Tan et al., ${ }^{[23]}$ demonstrated that highest IgE levels were found in CD14 -159C/ -1,145A/-1,359T haplotype as compared to other haplotypes; also they hypothesized that CD14 gene variants may play an important role in influencing allergen sensitization of children in Taiwan.

In this study, variability in the degree of allergy is explained by three successive steps: first, CD14 may recognize aeroallergens, such as dust mites. Second, it influences switching of the $\mathrm{T}$ helper cell response by enhancing production of interleukin (IL-12). Third, it leads to maturation of naïve $\mathrm{T}$ cells into type 1 helper $\mathrm{T}$ cells, and finally, it causes down-regulation of TH2 cells, and decreased immunoglobulin IgE production ${ }^{[40]}$. Polymorphisms in the CD14 promoter region have been associated with variability of atopic diseases and IgE levels. 
When the study population was divided according to HDM allergen concentration (Der $p$ 1) (Table 5), there was a significant difference of genotype distributions at $\mathrm{A}(-1,145) \mathrm{G}$ for homozygote $\mathrm{GG}$ genotype only $(P=0.02)$. Significant difference of GG genotype of $G(-1,359) \mathrm{T}$ polymorphism association to mite-sensitive subjects than other polymorphisms i.e of $\mathrm{C}(-159) \mathrm{T} / \mathrm{A}(-1,145)$ $\mathrm{G}$ among Taiwanese asthmatic children was reported by Tan et al., ${ }^{[23]}$. Kowal et al., ${ }^{[15]}$ hypothesized that a possible genetic interaction between CD14 and serpin 1 may influence susceptibility to HDM-allergic asthma through an effect by those genes on different aspects of bronchial reactivity and IgE response. Moreover, in Poland, a study reported a significant positive correlation between HDM allergen concentrations in household and sensitization to HDM for CD14/-159 CC and CD14/-1,359 GG genotype ${ }^{[16]}$. Also, increased HDM exposure with reduced incidence of atopy was found for the whole population and subjects with CD14/-159 CC, CD14/-1,359 GT. On contrary, an opposite hypothesis was raised in another study which concluded that increasing endotoxin exposure was associated with reduced risk of allergic sensitization and eczema, but increased risk of non-atopic wheeze in children with CC genotype at -159 of the gene encoding CD14 ${ }^{[19]}$.

It is concluded that CD14 gene polymorphisms may affect susceptibility level of allergen sensitization and associated with the development of variable atopic diseases. However, reports are conflicting and further population studies are recommended.

Author contribution: WM Zaki proposed the research idea and the study design, contributed in sample collection, laboratory procedures, and prepared the final version for submission. HA Salem and ME Ajeeby shared in the study design, sample collection, and revised the manuscript. HA El-Azizy was responsible for acquisition, analysis and interpretation of resulting data.

Acknowledgment: The authors express their gratitude to Prof. Dr. Sherif M. Abaza, Medical Parasitology Department, Faculty of Medicine, Suez Canal University, for his beneficial revision of the manuscript. The authors would like to express their gratitude to the Medical Laboratory technicians at Prince Mohamed Bin-Nasser, Abu-Erish, and Sabia hospitals for their cooperation in sample collection.

Conflict of interest: There is no conflict of interest. Financial support and sponsorship: This study received support and funding from the Deanship of Scientific Research, Jazan University, Jazan, KSA Funding number FS5-081.

\section{REFERENCES}

1. Portnoy J, Miller JD, Williams PB, Chew GL, Miller JD, Zaitoun F, et al. Environmental assessment and exposure control of dust mites: a practice parameter. Ann Allergy Asthma Immunol 2013; 111(6):465-507.

2. Bessot JC, Pauli G. Mite allergens: an overview. Eur Ann Allergy Clin Immunol 2011; 43:141-156.

3. Jacquet A. Innate immune responses in house dust mite allergy. ISRN Allergy 2013; 2013:735031.

4. Holloway JW, Yang IA, Holgate ST. Genetics of allergic disease. J Allergy Clin Immunol 2010; 125 (2 Suppl. 2):S81-94.

5. Kay AB. Allergy and allergic diseases. First of two parts. N Engl J Med 2001; 4; 344(1):30-37.

6. Akira $\mathrm{S}$, Hemmi $\mathrm{H}$. Recognition of pathogenassociated molecular patterns by TLR family. Immunol Lett 2003; 85:85-95.

7. Rescigno M, Granucci F, Ricciardi-Castagnoli P. Molecular events of bacterial-induced maturation of dendritic cells. J Clin Immunol 2000; 20 (3):161166.

8. Galli, SJ, Tsai M, Piliponsky, AM. The development of allergic inflammation. Nature 2008; 454, 7203, 445-454.

9. Leung TF, Tang NL, Sung YM, Li AM, Wong GW, Chan IH, et al. The C-159T polymorphism in the CD14 promoter is associated with serum total IgE concentration in atopic Chinese children. Pediatr Allergy Immunol 2003; 14(4): 255-260.

10. Foster SL, Medzhitov R. Gene-specific control of the TLR-induced inflammatory response. Clin Immunol 2009; 130(1):7-15.

11. Bucková D, Hollá LI, Schüller M, Znojil V, Vácha J. Two CD14 promoter polymorphisms and atopic phenotypes in Czech patients with IgE-mediated allergy. Allergy 2003; 58(10):1023-1026.

12. Zamani F, Zare Shahneh F, Aghebati-Maleki L, Baradaran B. Induction of CD14 Expression and differentiation to monocytes or mature macrophages in promyelocytic cell lines: New Approach. Adv Pharm Bull 2013; 3(2):329-332.

13. Vercelli D, Baldini M, Stern D, Lohman IC, Halonen M, Martinez F. CD14: a bridge between innate immunity and IgE responses. J Endotoxin Res 2001; 7:45-48.

14. Saçkesen C, Karaaslan C, Keskin O, Tokol N, Tahan $\mathrm{F}$, Civelek E, et al. The effect of polymorphisms at the CD14 promoter and the TLR4 gene on asthma phenotypes in Turkish children with asthma. Allergy 2005; 60 (12):1485-1492.

15. Kowal K, Bodzenta-Łukaszyk A, Pampuch A, Szmitkowsk M, Zukowski S, Donati MB, et al. Analysis of -675 4G/5G serpine1 and C-159T CD14 polymorphisms in house dust mite-allergic asthma patients. J Invest Allergol Clin Immunol 2008; 18: 284-292.

16. Kurowski M, Majkowska-Wojciechowska B, Wardzyńska A, Kowalski ML. Associations of allergic sensitization and clinical phenotypes with innate immune response genes polymorphisms are modified by house dust mite allergen exposure. Arch Med Sci 2011; 31;7 (6):1029-1036. 
17. Baldini M, Lohman IC, Halonen M, Erickson RP, Holt PG, Martinez FD. A polymorphism in the 5' flanking region of the CD14 gene is associated with circulating soluble CD14 levels and with total serum Immunoglobulin E. Am J Respir Cell Mol Biol 1999; 20 (5):976-983.

18. Arbour NC, Lorenz E, Schutte BC, Zabner J, Kline JN, Jones $\mathrm{M}$, et al. TLR4 mutations are associated with endotoxin hypo-responsiveness in humans. Nat Genet 2000; 25(2):187-191.

19. Simpson A, John SL, Jury F, Niven R, Woodcock A, Ollier WE, et al. Endotoxin exposure, CD14, and allergic disease: an interaction between genes and the environment. Am J Respir Crit Care Med 2006; 15; 174(4):386-392.

20. Reddel HK, Bateman ED, Becker A, Boulet LP, Cruz AA, Drazen JM, et al. A summary of the new GINA strategy: a roadmap to asthma control. Eur Respir J 2015; 46(3):622-639.

21. Cirillo I, Klersy C, Marseglia G, Tosca M, Ciprandi G. Screening spirometry to detect respiratory allergy. Eur Ann Allergy Clin Immunol 2006; 38(5):146148.

22. Heikal HM. Studies on the occurrence, identification and control of house dust mites at rural houses of Shebin El-Kom locality, Egypt. Pak J Biol Sci 2015; 18: 179-184.

23. Tan CY, Chen YL, Wu LSH, Liu CF, Chang WT, Wang JY. Association of CD14 promoter polymorphisms and soluble CD14 levels in mite allergen sensitization of children in Taiwan. J Hum Genet 2006; 51:59-67.

24. Vercelli D. Genetics, epigenetics, and the environment: switching, buffering, releasing. J Allergy Clin Immunol 2004; 113: 381-386.

25. Kusunoki $\mathrm{T}$, Nakahata $\mathrm{T}$, Miyanomae $\mathrm{T}$, Inoue $\mathrm{Y}$. Possible dual effect of CD14 molecule on atopy. Am J Respir Crit Care Med 2002; 165:551-552.

26. Levan TD, Michel O, Dentener M, Thorn J, Vertongen $\mathrm{F}$, Beijer L, et al. Association between CD14 polymorphisms and serum soluble CD14 levels: effect of atopy and endotoxin inhalation. J Allergy Clin Immunol 2008; 121:434-440.

27. Munthe-Kaas MC, Torjussen TM, Gervin K, Lødrup Carlsen KC, Carlsen KH, Granum B, et al. CD14 polymorphisms and serum CD14 levels through childhood: A role for gene methylation? J Allergy Clin Immunol 2010; 125:1361-1367.

28. Lachheb J, Dhifallah IB, Chelbi H, Hamzaoui K, Hamzaoui A. Toll-like receptors and CD14 genes polymorphisms and susceptibility to asthma in Tunisian children. Tissue Antigens 2008; 71(5):417-425.

29. Ghaemmaghami AM, Shakib F. Human T cells that have been conditioned by the proteolytic activity of the major dust mite allergen $\operatorname{Der} p 1$ trigger enhanced immunoglobulin E synthesis by B cells. Clin Exp Allergy 2002; 32:728-732.

30. Brown A, Farmer K, MacDonald L, Kalsheker N, Pritchard D, Haslett C, et al. House dust mite Der $p 1$ downregulates defenses of the lung by inactivating elastase inhibitors. Am J Respir Cell Mol 2003; 29: 381-389.

31. Deb R, Shakib F, Reid K, Clark H. Major house dust mite allergens Dermatophagoides pteronyssinus 1 and Dermatophagoides farinae 1 degrade and inactivate lung surfactant proteins A and D. J Biol Chem 2007; 282: 36808-36819.

32. Newton GK, Perrior TR, Jenkins K, Major MR, Key $\mathrm{RE}$, Stewart MR, et al. The discovery of potent, selective, and reversible inhibitors of the house dust mite peptidase allergen $\operatorname{Der} p$ 1: an innovative approach to the treatment of allergic asthma. J Med Chem 2014; 57(22):9447-9462.

33. Reddy VB, Lerner EA. Activation of mas-related G-protein-coupled receptors by the house dust mite cysteine protease Der $p 1$ provides a new mechanism linking allergy and inflammation. J Biol Chem 2017; 292(42):17399-17406.

34. Heinzmann A, Dietrich $H$, Jerkic SP, Kurz $T$, Deichmann KA. Promoter polymorphisms of the CD14 gene are not associated with bronchial asthma in Caucasian children. Eur J Immunogen 2003; 30: 345-348.

35. Micheal S, Minhas K, Ishaque M, Ahmed F, Ahmed A. Promoter polymorphisms of the CD14 gene are associated with atopy in Pakistani adults. J Investig Allergol Clin Immunol 2011; 21(5): 394-397.

36. de Faria ICJ, de Faria EJ, Toro AADC, Ribeiro JD, Bertuzzo CS. Association of TGF-ß1, CD14, IL-4, IL4R and ADAM33 gene polymorphisms with asthma severity in children and adolescents. J Pediatr (Rio J) 2008; 84:203-210.

37. Alsulaimani1 AD, Awad NS, El-Tarras AE. Genetic basis of childhood asthma in Saudi Arabia. Int J Curr Microbiol App Sci 2015; 4(6): 317-325.

38. Han D, She W, Zhang L. Association of the CD14 gene polymorphism $\mathrm{C}$-159T with allergic rhinitis. Am J Rhinol Allergy 2010; 24(1): e1 3.

39. Rennie DC, Karunanayake C, Chen Y, Nakagawa K, Pahwa P, Senthilselvan A, et al. CD14 gene variants and their importance for childhood croup, atopy and asthma. Dis Markers 2013; 35(6): 765 -771.

40. Hollgate ST. Genetic and environmental interaction in allergy and asthma. J Allergy Clin Immunol 1999; 104(6): 1139-1146. 